\section{AUTHORS:}

Robert Luetkemeier ${ }^{1,2}$

Meed Mbidzo ${ }^{3}$ iD

Stefan Liehr ${ }^{1,2}$ iD

\section{AFFILIATIONS:}

IInstitute for Social-Ecological Research, Frankfurt, Germany

${ }^{2}$ Senckenberg Biodiversity and Climate Research Centre, Frankfurt Germany

${ }^{3}$ Department of Agriculture and

Natural Resources Sciences, Namibia University of Science and Technology, Windhoek, Namibia

\section{CORRESPONDENCE TO:}

Robert Luetkemeier

EMAIL:

luetkemeier@isoe.de

DATES:

Received: 03 Jan. 2020

Revised: 10 July 2020

Accepted: 27 July 2020

Published: 29 Jan. 2021

\section{HOW TO CITE:}

Luetkemeier R, Mbidzo M, Liehr $\mathrm{S}$. Water security and rangeland sustainability: Transdisciplinary research insights from NamibianGerman collaborations. S Afr J Sci. 2021;117(1/2), Art. \#7773. https:// doi.org/10.17159/sajs.2021/7773

\section{ARTICLE INCLUDES:}

囚 Peer review

$\square$ Supplementary material

\section{DATA AVAILABILITY:}

$\square$ Open data set

$\square$ All data included

$\square$ On request from author(s)

$\otimes$ Not available

$\square$ Not applicable

EDITOR:

Jane Carruthers (ID

\section{KEYWORDS:}

interdisciplinarity, transdisciplinarity,

sustainable development, co-

knowledge production, Namibia

\section{FUNDING:}

German Federal Ministry of Education and Research

\title{
Water security and rangeland sustainability: Transdisciplinary research insights from Namibian- German collaborations
}

\begin{abstract}
The Global South is facing severe challenges in ensuring livelihood security due to climate change impacts, environmental degradation and population growth as well as changing lifestyles. These complex problems cannot be solely solved by single scientific disciplines - they require transdisciplinary research (TDR). Stakeholders from civil society, the corporate sector, government and science need to pool their knowledge to find solutions for sustainable transformations. In Namibia, we have been involved in TDR projects on water supply, and sanitation services as well as livestock management in rangeland systems. In this paper, we review two TDR projects that differ in multiple ways and hence allow us to carve out structural differences and critically discuss research outcomes, lessons learned and the challenge of North-South collaborations. Our review builds upon published and unpublished project documents as well as expert interviews with Namibian and German researchers who were involved in the projects. Our results show that TDR can be put into practice in different ways, depending on the research focus and the period available. The TDR phases of problem framing, inter- and transdisciplinary integration were implemented with different tools and foci points. We discuss the role of project length and funding conditions for project success and outcome generation. In addition, we critically consider the role of Namibian and German researchers in these international collaborations. The conclusions we draw touch upon the points of preparatory research funding, the equal acknowledgement of Global South contributions to joint research projects and the explicit handling of TDR components in project work.
\end{abstract}

\section{Significance:}

- The current social-ecological challenges are complex and require TDR as a mode of knowledge coproduction, particularly in a development context.

- Inter- and transdisciplinary integration are critical processes for a project to be successful and require the allocation of adequate time and monetary resources.

- $\quad$ Longer-term projects with a funded preparatory research phase constitute a structural model for TDR as project outcomes can evolve over time.

- Global South researchers carry a hidden burden in international collaborations that has to be adequately acknowledged upfront in project planning and final products.

\section{Introduction}

The challenges humanity faces today, especially in countries south of the Sahara, are unprecedented. Poverty, inequality and hunger as well as unsafe water supply, unimproved sanitation and infectious diseases remain some of the key problems for millions of people ${ }^{1}$, although progress is visible with more and more people reaching good standards of living ${ }^{2}$. These societal challenges are interrelated with climate change impacts, environmental degradation, population growth, urbanisation and changing lifestyles in a complex pattern. ${ }^{3}$ They become 'wicked problems' for which by definition 'one-size-fits-all' solutions are not available. ${ }^{4}$

The Sustainable Development Goals (SDG) create a positive vision of the future by targeting good living conditions for all by $2030 .{ }^{5}$ However, the key question remains: how can these conditions be created against the background of complex non-linear cause-effect relations in social-ecological systems? For decades, global-scale approaches such as the World3 model ${ }^{6}$, the Planetary Boundaries ${ }^{7}$ and the 'Doughnut'8 attempted to disentangle socialecological interactions, claiming to provide applicable knowledge for societal problems. However, apart from their ability to guide global agenda setting and to raise awareness of humanity's role in the Anthropocene ${ }^{9}$, their power to inform local decision-making in order to guide sustainable transformations ${ }^{10}$ remains to be tested ${ }^{11}$.

The local scale is, however, the most relevant level at which sustainable transformations take place. ${ }^{12}$ With increasing interest, transdisciplinary research (TDR) is regarded by practitioners and scholars as a suitable approach to design sustainable development paths adapted to local particularities. ${ }^{13}$ Challenges in natural resources management are complex in ontological, analytical and social terms and require decisive boundary work for transdisciplinary teams to achieve outcomes that can be taken up by practitioners. ${ }^{14}$ Therefore, TDR is not considered a theory, a methodology or an institution, but rather an approach to developing solutions for societal challenges in which relevant and applicable knowledge is co-produced by both scientists and stakeholders. ${ }^{15}$ Particularly against the background of sub-optimal outcomes from non-integrated research and development projects, e.g. in the form of persisting implementation gaps ${ }^{16}$, TDR can be considered a promising approach to solve sustainability challenges, especially in the Global South ${ }^{17}$. For this solution to be fruitful, facilitating factors such as the importance of project co-creation and the role of knowledge brokers against issues such as preconceived assumptions, silothinking and terminological diversity have already been identified. ${ }^{18}$ Despite the growing recognition of TDR and
(C) 2021. The Author(s). Published under a Creative Commons Attribution Licence. 
its potential, particularly in sub-Saharan Africa, capacities of scientists and stakeholders on how to successfully conduct TDR projects are still evolving. ${ }^{19}$ Although success criteria of TDR have been identified ${ }^{20}$, particular demands persist in both the Global North and South for capacity development to design, implement, monitor and evaluate TDR projects.

In this paper, we, as a Namibian-German team of authors, intend to share our experiences from two TDR projects in Namibia on water and food security ${ }^{21}$ and rangeland sustainability 22 to contribute to meet the abovementioned demands. We do not intend to provide a comprehensive evaluation of each project as this would require more resources to acknowledge the diverse set of valuations and expectations from research funders, research providers and research users. ${ }^{23}$ Our objectives are rather to (1) present key insights into structural project implementation stages and (2) to discuss the projects' major outcomes and lessons learned as well as the role of German and Namibian researchers within these North-South collaborations.

\section{Material and methods}

In order to meet these objectives, we reviewed two research projects that were carried out in Namibia between 2006 and 2017. The following subsections will briefly shed light on the case study approach we followed, the expert interviews we conducted and the TDR process we used as a reference to structure our results.

\section{Case study approach}

TDR projects provide a context-specific forum for all parties involved to learn from and with each other. This mutual learning process enables them to 'learn to collaborate while collaborating' as Freeth and Caniglia ${ }^{24}$ aptly phrased it recently. While most project parties may benefit from this, it remains an asset that is hard to access for third parties. Therefore, we consider a case study approach as a suitable tool to provide thirdparty scientists and practitioners with insights from past TDR projects.

Taking a closer look at the scientific TDR literature confirms this impression as case study reports are a common format to make TDR insights available to third parties. For instance, Roux et al. ${ }^{23}$ report on research programmes from South Africa on water management, landuse change, food production and river system health and propose a co-reflection framework that facilitates the evaluation of TDR projects. Cundill et al. ${ }^{25}$ reviewed projects from the USA and South Africa on urban water management and freshwater conservation to explore the role of 'communities of practice' in facilitating knowledge sharing and mutual learning processes. Freeth and Caniglia ${ }^{24}$ share their experiences from a project that took a systemic perspective on leverage points to identify root causes of unsustainability.

Here, we take a closer look at two projects that were conducted as joint collaborations among Namibian and German partners. We deliberately chose two projects that differ from each other in multiple ways, i.e. in their thematic focus, the time periods available and the degree of stakeholder involvement. We report on the CuveWaters ${ }^{21}$ project in which an Integrated Water Resources Management (IWRM) scheme was developed for northern Namibia and on the project OPTIMASS ${ }^{22}$ in which rangeland sustainability was assessed on freehold farms in the northeast of Namibia.

\section{Expert interviews}

While a comprehensive evaluation of the two projects is not the subject of this paper, we intend to shed light on particular issues of TDR that are rather intangible and often not made explicit during and after project work. In this regard, the term 'outcomes' refers to long-term changes in social-ecological structures and processes (e.g. new routines, governance structures) that go beyond short-term project outputs such as reports, papers and toolkits. ${ }^{26}$ We also critically discuss lessons learned from both projects with regard to the way TDR was initiated and carried out. Against these experiences, we try to provide constructive suggestions on how to bypass respective challenges in future projects. Finally, we reflect upon the roles of Namibian and German researchers in these joint collaborations that were funded by the German Federal Ministry for Education and Research. Therewith, we want to provide a critical contribution to the design and implementation of TDR in NorthSouth collaborations.

In order to achieve these objectives, a review of published and unpublished internal reports is a necessary first step. However, we assumed that more detailed information could be obtained from former project members who were involved in the design, implementation and finalisation phases of the projects. Semi-structured, systematising expert interviews ${ }^{27}$ were hence regarded as a suitable tool to further expand our own experiences and the information we gained from the literature. Expert interviews are common tools to obtain information, perceptions and viewpoints on structural aspects of TDR projects. For instance, Zscheischler et al. ${ }^{20}$ carried out qualitative expert interviews on success factors of TDR to compile a quantitative questionnaire thereof. Defila and Di Giulio ${ }^{28}$ consider the challenge of knowledge integration and carried out qualitative interviews with researchers and stakeholders of multiple projects from a common funding scheme on project organisation, implementation, collaboration, common goals and the design of synthesis products.

For the current study, we carried out five systematising expert interviews with former project members - three Namibians and two Germans who were leading researchers on the projects. The semi-structured interview guideline consisted of open questions on (1) major project outcomes, (2) shortcomings and lessons learned as well as (3) the role of Namibian and German researchers. The interviews provided room for additional comments and statements, while three of them were conducted as face-to-face conversations and two experts provided their answers in written form. All interviews were noted, digitised and coded for a qualitative content analysis. The coding scheme was deducted from the interview guideline and inductively adjusted while working on the transcripts. Ethical clearance to conduct the interviews was provided by the Ethics Commission of the Institute for Social-Ecological Research, Frankfurt, Germany.

\section{Transdisciplinary research process}

Today's wicked social-ecological problems require a mode of science that can guide sustainable transformations. While notions of this mode of research may vary from 'mode 2 science', 'action research', 'team science' or 'post-normal science', the conceptual target behind these notions is to generate 'socially robust' knowledge. ${ }^{15}$ This understanding acknowledges the necessity and strengths of mono-, multi- and interdisciplinary forms of knowledge production ${ }^{29}$, but critically highlights the need to go beyond science in order to co-produce new applicable knowledge.

Overall, the term TDR is not strictly defined, resulting in different interpretations and priority settings. To give a brief introduction into the corresponding literature for the African context, research on water conservation, for instance, highlights the role of mutual learning processes among stakeholders and scientists as a key feature of TDR and its role for overall project success. ${ }^{30,31}$ Against this background, $\mathrm{Nel}$ et al. ${ }^{32}$ conceptualised a framework to guide river and wetland conservation planning and co-knowledge production from a South African case study. They propose a three-tiered process of (1) project co-design, (2) knowledge co-production and (3) co-implementation with an iterative process of knowledge sharing and mutual learning among the participating parties. ${ }^{32}$ Their perspective comes close to conceptual works on TDR in global research endeavours under the umbrella of the Future Earth programme. In this context, Mauser et al. ${ }^{13}$ propose a similar framework with consecutive steps of (1) co-design, (2) coproduction and (3) co-dissemination in which different aspects of integration (scientific, international and sectoral) become relevant.

In the projects under consideration here, we applied a conceptual TDR framework that links to the above-mentioned examples. ${ }^{15}$ It comprises three idealised phases of (1) problem framing, (2) interdisciplinary integration and (3) transdisciplinary integration as depicted in Figure 1. 


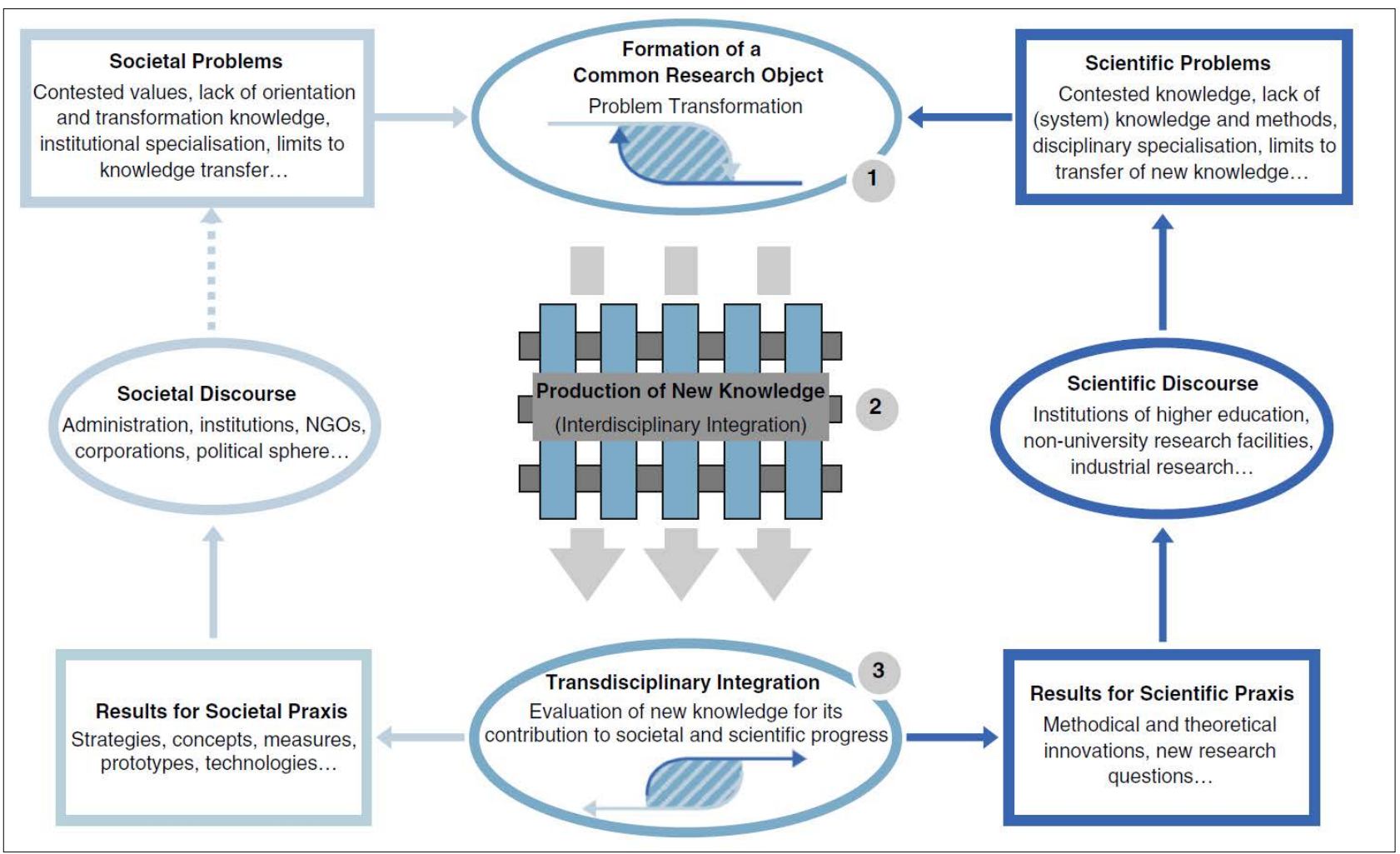

Figure 1: Conceptual model of an idealised transdisciplinary research process..$^{15}$

Initially, phase 1 of problem framing is required in which stakeholders from relevant fields as well as scientists frame their particular interests in order to find a common ground. Ideally, all parties agree upon a 'boundary object' which is basically a shared conceptual understanding of the overall problem context. Once this is found, it can be used to create an 'epistemic object', which is a more precisely defined concept, such as a social-ecological system. ${ }^{33}$ This epistemic object serves as a tool for organising knowledge from different stakeholder perspectives and provides the opportunity for mutual learning. From here, phase 2 commences in which a more conventional interdisciplinary science process starts. ${ }^{15}$ For this purpose, the overall research question needs to be broken down into smaller pieces that can be worked upon by individual scientific disciplines. In these packages, disciplinary and interdisciplinary work on specific research questions is conducted with two aims: (1) while the major target is to obtain scientific insights that support the overall project goal, (2) the process also targets the production of new knowledge for individual disciplinary communities. The researchers hence work on their specific disciplinary questions that are relevant to their own fields, and need to generate results that are relevant for their colleagues as part of the interdisciplinary effort within the TDR. In phase 3, the results from the individual work packages and disciplines are finally integrated to generate knowledge products that are target group specific and can be fed back into the societal and the scientific discourses. ${ }^{15}$

\section{Results}

The results of the project reviews are structured as follows. First, the idealised TDR phases are considered to elaborate upon structural differences between the projects and to shed light on specific aspects of how TDR can be put into practice. Second, major outcomes, lessons learned and challenges in North-South collaborations are presented and critically discussed. At the beginning of each section, the results are summarised in a table while key aspects therein are elaborated on in the associated paragraphs.

\section{Project phases}

The idealised TDR process provides a guideline to structure the key aspects of project implementation. We made an attempt to assign certain project activities to each of the TDR phases in order to carve out similarities and differences between the case studies. Table 1 gives a comparative overview of selected project features in this regard.

\section{Problem framing}

The initial phase of TDR serves the purpose of finding a common understanding of a given real-world problem from both societal and scientific viewpoints. ${ }^{15}$ Theoretically, this process can be considered a bottom-up process in which researchers and stakeholders discuss pressing problems and agree upon shared definitions. In practice however, this requirement is difficult to be met, as the funding frameworks broadly pre-define a thematic area in which researchers and stakeholders are required to operate, although these thematic areas may not necessarily cover the challenges most relevant, locally.

Nevertheless, leaving this strict interpretation aside, both projects managed to facilitate a collaborative problem-framing process. In CuveWaters, the funding agency expected a preparatory phase in which German and Namibian researchers and stakeholders were able to adjust the initial project design according to local needs. This preparatory phase turned out to be a valuable first step to render the project proposal more relevant to local real-world challenges. In the case of OPTIMASS, a preparatory phase was not available, but the project design was still considered efficient by the interviewed experts as German and Namibian researchers could fall back on prior collaborations which facilitated mutual understanding. Nevertheless, full integration of scientists and stakeholders in OPTIMASS was only possible after official project launch. The benefit of preparatory phases or 'quick initiation funding' was already highlighted by scholars like Luthe ${ }^{34}$ for TDR research in general and by Giller ${ }^{35}$ for North-South collaborations. Respective programmes are now increasingly considered in funding schemes, e.g. by German Federal Ministry for Education and Research and the Dutch Research Council. 
Table 1: Comparative overview on key features of the idealised transdisciplinary research stages

\begin{tabular}{|c|c|c|c|}
\hline & Features & CuveWaters & OPTIMASS \\
\hline Duratio & & $2006-2015$ (10 years) & $2014-2017$ (3 years) \\
\hline Focus & & Improving water and food security in central-northern Namibia & $\begin{array}{l}\text { Shaping sustainable human-nature interactions in rangeland } \\
\text { systems of Namibia }\end{array}$ \\
\hline .읕 & Preparation & $\begin{array}{l}\text { Overall research scope was pre-defined by funding scheme. } \\
\text { Extensive scoping phase for Namibian-German researchers } \\
\text { and stakeholders prior to project start (workshops, field visits). }\end{array}$ & $\begin{array}{l}\text { Overall research scope was pre-defined by funding scheme. } \\
\text { Prior Namibian-German collaboration facilitated project design. } \\
\text { However, start of intensive problem framing after project } \\
\text { launch (workshops, field visits). }\end{array}$ \\
\hline 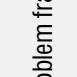 & Boundary object & $\begin{array}{l}\text { 'Integrated Water Resources Management' as overall reference } \\
\text { concept well known to all partners }\end{array}$ & $\begin{array}{l}\text { 'Sustainable Geo-Biosphere Feedback Management' as tangible } \\
\text { notion for scientists, stakeholders and farmers }\end{array}$ \\
\hline & Epistemic object & $\begin{array}{l}\text { 'Multi-resources mix' narrative describing the activation of } \\
\text { multiple endogenous water potentials for improvement of } \\
\text { supply autonomy, food security and job creation }\end{array}$ & $\begin{array}{l}\text { 'Ecosystem Services in Rangelands' as depiction of the } \\
\text { interconnectedness of livestock-based farm management and } \\
\text { rangeland ecosystem responses }\end{array}$ \\
\hline & Major disciplines & $\begin{array}{l}\text { Agriculture, geography, sociology, social ecology, hydraulic } \\
\text { engineering }\end{array}$ & Plant ecology, hydrology, geography, social ecology \\
\hline 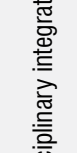 & Disciplinary work & $\begin{array}{l}\text { Integrated work packages on four technologies, each with } \\
\text { research questions of (1) technical and institutional design, (2) } \\
\text { capacity development for operation and maintenance and (3) } \\
\text { social and ecological impact evaluation }\end{array}$ & $\begin{array}{l}\text { Disciplinary work packages on eco-hydrology, vegetation- } \\
\text { environment feedbacks, rangeland management and water } \\
\text { management }\end{array}$ \\
\hline 垴 & Integration & $\begin{array}{l}\text { The concepts of 'knowledge', 'practices', 'institutions' and } \\
\text { 'technology' served as arenas for interdisciplinary exchange } \\
\text { within and beyond the work packages }\end{array}$ & $\begin{array}{l}\text { Integration across work packages was established by a formal } \\
\text { model that required input from environmental and societal } \\
\text { control variables to depict rangeland-ecosystem feedbacks }\end{array}$ \\
\hline 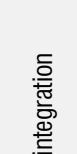 & Stakeholders & $\begin{array}{l}\text { National and local level institutional stakeholders, primarily } \\
\text { governmental/administrative actors were involved over the } \\
\text { entire project duration. Ownership of facilities transferred to } \\
\text { these stakeholders in final project phase. }\end{array}$ & $\begin{array}{l}\text { Collaboration primarily with local administrative stakeholders } \\
\text { and freehold farmers in the study area. Actors from the } \\
\text { Namibian agricultural sector were involved for knowledge } \\
\text { transfer. }\end{array}$ \\
\hline 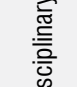 & Population & $\begin{array}{l}\text { Technology development and adaptation was co-designed with } \\
\text { local population as direct users of new technologies }\end{array}$ & $\begin{array}{l}\text { Farmers were directly engaged for collaborative development } \\
\text { of farm-management strategies }\end{array}$ \\
\hline 帝 & Output & $\begin{array}{l}\text { Practice-oriented knowledge products (e.g. manuals, toolkits) } \\
\text { and demonstration plants were established to ensure } \\
\text { continuation of activities and facilitation of imitators }\end{array}$ & $\begin{array}{l}\text { Knowledge transfer via conference and fair talks, workshops } \\
\text { and booklets primarily for farmers }\end{array}$ \\
\hline
\end{tabular}

In practical terms, the problem-framing phases in both projects included a number of activities such as inter- and transdisciplinary workshops and field visits. In the case of CuveWaters, the IWRM concept can be considered as the boundary object on which all actors could agree. During the time of project launch, IWRM was the leading paradigm in the water sector ${ }^{36}$ to which all stakeholders could connect. The parties involved further concretised what IWRM meant in the project context and created the notion of a multi-resources mix ${ }^{37}$ which can be considered the epistemic object of the project. As a narrative, it summarises the broad range of endogenous water resources that should be utilised to sustainably enhance local living conditions.

In a similar manner, researchers and stakeholders in OPTIMASS found a common language by referring to the notion of 'Sustainable GeoBiosphere Feedback Management' as the weakly structured boundary object. It served as an intuitive representation of how farmers and their livestock interact with the environment. This notion was further concretised by referring to 'Ecosystem Services of Rangelands' - a conceptual understanding which became a key term in current rangeland science in combination with the concept of resilience. ${ }^{38}$ This facilitated the integrated discussions on how certain management actions alter ecosystem functions and hence relevant ecosystem services for farmers.

\section{Interdisciplinary integration}

The second phase of TDR provides room for new knowledge to be produced by the involved disciplines in a collaborative way. While multiple options to facilitate interdisciplinary integration in a TDR context exist, such as theoretical framing, collaborative formulation of integrated hypothesis or development and application of integrated models ${ }^{39}$, a method's suitability for particular projects is always context specific.

Both projects included a range of disciplines from natural, social and engineering sciences, but followed different paths of interdisciplinary integration. CuveWaters adopted an organisational structure in which the different technological interventions were conceptualised as individual work packages. In this regard, each work package was set up in an interdisciplinary way to work on (1) the technical and institutional design, (2) capacity development for operation and maintenance and (3) social and ecological impact evaluation. While interdisciplinary collaboration was hence already conducted at this stage, further arenas for exchange between the work packages were established by regularly discussing progress in empirical and conceptual work under the umbrella concepts of 'institutions', 'practices', 'technologies' and 'knowledge', referred to as the social-ecological structures and processes. ${ }^{40}$ This multi-level approach is considered suitable for projects with a larger spectrum of interventions. 
OPTIMASS chose a different way by not designing the individual work packages explicitly in an interdisciplinary way but rather integrating the individual disciplinary activities in an overarching formal model that depicts rangeland feedbacks. In this regard, the work packages focused on specific disciplinary tasks in the fields of eco-hydrology, vegetation-environment feedbacks, rangeland management and water management. The project integrated the individual perspectives by using the 'EcoHyD' model which simulates the coupled hydrological and vegetation dynamics taking into account changes in landscape and climate. ${ }^{41}$ This was flanked by the conceptual elaboration of the feedback processes between humans and rangelands as a social-ecological system. Although the formal model was not specifically tailored towards the integration of different knowledge domains, the researchers were able to clearly identify their particular contribution to the overall research aim and used the model to put themselves in relation to the other disciplines. Research questions that were addressed in this phase of interdisciplinary integration were (1) which ecological indicators are relevant to farmers in deciding on management actions, (2) which drought adaptation strategies are being carried out, and (3) how these strategies of farmers can be translated in parameters with realistic value ranges for model simulations.

\section{Transdisciplinary integration}

Although the third stage of the idealised TDR process may visually be interpreted as the final phase (Figure 1), it can be thought of as a continuous process of mutual learning in which knowledge transfer towards society gains importance by the end of the project. ${ }^{15}$ The following paragraphs describe the way institutional stakeholders and individual local actors were involved in the research processes and what types of knowledge products were generated.

CuveWaters involved a broad range of governmental and nongovernmental stakeholders that were selected according to their relevance for project implementation and their potential for regional and national policy outreach as well as based on existing personal and institutional relations. In particular, ministerial departments, the national water supplier and river basin committees have been of primary importance and participated regularly in project activities. ${ }^{42}$ In terms of local actors, the project particularly involved community members in the design, operation and maintenance of the technological and institutional interventions to ensure their applicability and their postproject continuation. Bottom-up processes were initialised via co-design processes including regular workshops, focus group discussions and trainings. ${ }^{43}$ Tailored knowledge products were generated and communicated to the relevant actors. This science-society interface included elements such as workshops, leaflets, films, policy briefs, toolkits and information systems. For instance, a rain and floodwater harvesting toolkit gives practical advice on how to design, construct and operate water harvesting facilities and the 'Interactive Water Information System' provides spatially explicit information on environmental aspects and project results for water managers. ${ }^{44}$

OPTIMASS put a stronger emphasis on national stakeholders from the environmental and agricultural sector. While similar selection criteria were applied as in CuveWaters, prior collaborations facilitated the initial stakeholder engagement process. In this regard, the Ministry of Environment and Tourism and the Namibian farmers' unions were involved. As key landscape managers in the study area, local freehold farmers were engaged in OPTIMASS as the primary addresses and collaborators. Local actors often hold implicit knowledge on ecosystem dynamics that can be valuable to complement and inform explicit scientific knowledge. ${ }^{45}$ Local and traditional knowledge systems with a particular focus on natural resources management can also be referred to as 'professional ecological knowledge' ${ }^{46}$ Hence, the farmers were included in the project as equal partners to understand feedbacks in rangeland management and to develop adapted management strategies that build upon currently available practices. While researchers made use of qualitative and quantitative social science methods to obtain firsthand knowledge (consultation of stakeholders ${ }^{47}$ ), farmers could engage with the project team on an equal basis via workshops, focus group discussions and field experiments (participation of stakeholders ${ }^{47}$ ). ${ }^{48}$ In terms of output, the project designed knowledge products such as booklets with condensed results for farmers and the general public ${ }^{22}$ and communicated practical knowledge to the agricultural sector and the farmers beyond the local study area by hosting the '21st Namibian Rangeland Forum' in 201749. Furthermore, mentoring of farmers and involving them in experimental settings was uncovered as a suitable mechanism to transfer knowledge between farmers. In addition, respected experts, e.g. experienced farmers who are acknowledged by their peer community and have a good reputation, can also act as multipliers for scientific knowledge transfer.

\section{Project insights}

The following paragraphs will take a closer look at the projects' impacts and what we learned from them. Here, the expert interviews can be considered as the major sources of information to carve out outcomes, lessons learned and challenges in North-South collaborations as presented in Table 2.

\section{Major outcomes}

TDR intends to create an impact on social-ecological structures and processes to initiate and accompany transformations towards sustainability. ${ }^{12}$ If successful, these long-term impacts can be considered as project outcomes that go beyond direct project outputs such as scientific papers, reports, toolkits and manuals. ${ }^{26}$ While Table 2 provides a brief overview of societal and scientific outcomes, the following paragraphs will take a closer look at outcomes on multiple societal levels.

At the local level, CuveWaters intervened with infrastructure and governance systems of water and food supply and hence directly affected the livelihoods of rural and urban inhabitants, mostly disadvantaged people. The consulted experts consider the co-design process to be largely successful, as behavioural routines of inhabitants changed (e.g. new hygienic habits), new occupational opportunities were created (e.g. maintainers/constructors locally known as 'blue team'), local authorities continued facility operations (e.g. sanitation and water reuse system) and households carried on water harvesting and gardening activities (e.g. income generation). As a result of these local level processes, one follow-up project was initiated that builds upon CuveWaters research and further investigates the potential of water reuse for fodder production and thus the alleviation of grazing pressure in northern Namibia (EPoNa) ${ }^{50}$ OPTIMASS investigated rangeland feedbacks in livestock-dominated savannah ecosystems and directly collaborated with local freehold farmers. While the three-year project primarily focused on understanding the ecological effects and interactions with societal drivers of rangeland feedbacks, farmers were engaged in developing farm management strategies that were locally applied and tested. The project identified indicators for farm decision-making (e.g. plant species composition and features) and developed recommendations on combining horizontal (e.g. rotational grazing with effects into the area) and vertical measures (e.g. de-bushing with soil-penetrating effects) to enhance soil water and vegetation conditions. ${ }^{48}$ This knowledge was locally applied and disseminated to other farmers. As a result of this process, trust between farmers and researchers was created, which led to the initiation of a follow-up project that further investigates degradation processes and tipping points in the same study area (NamTip). ${ }^{51}$

Besides the local level, both projects engaged with regional and national level stakeholders to generate outcomes. CuveWaters collaborated with authorities and non-governmental organisations throughout the country and beyond to disseminate the knowledge gained. In this regard, multiple spin-off initiatives were triggered that adopted the sanitation and water reuse approach as well as the rain and floodwater harvesting technologies for new problem contexts. Furthermore, an attempt was made to introduce the dualistic vocational training approach that proved to be successful in the project to the national regulations of formal training and education. OPTIMASS was able to feed the results into the national discourse, primarily by co-organising a national conference of the agricultural sector and by engaging with national-level stakeholders. In addition, a spin-off project could be initiated in a different region that investigates wildlife-based strategies as one option for sustainable rangeland management (ORYCS). ${ }^{52}$ 
Table 2: $\quad$ Overview on selected outcomes, lessons learned and issues of North-South collaboration

\begin{tabular}{|c|c|c|c|}
\hline & Features & CuveWaters & OPTIMASS \\
\hline \multirow{2}{*}{ 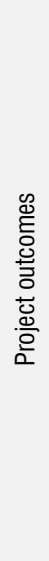 } & Society & $\begin{array}{l}\text { Co-developed interventions led to new behavioural routines } \\
\text { (hygiene practices) and occupational opportunities (income from } \\
\text { gardening) } \\
\text { Knowledge on sanitation and water reuse technologies } \\
\text { disseminated to other cities } \\
\text { Low-tech rain and floodwater harvesting and gardening techniques } \\
\text { were adopted by NGOs/households and implemented elsewhere }\end{array}$ & $\begin{array}{l}\text { Freehold farmers gained knowledge on ecosystem responses of } \\
\text { certain livestock farming practices and about options for adaptation } \\
\text { strategies for rangeland management } \\
\text { Trust among participating farmers and researchers was created } \\
\text { as willingness to collaborate in and openness towards follow-up } \\
\text { research projects increased }\end{array}$ \\
\hline & Science & $\begin{array}{l}\text { Insights into community organisation for efficient operation of } \\
\text { rainwater and gardening facilities } \\
\text { 'Demand-responsive' assessment procedure was developed to } \\
\text { facilitate co-design of technologies and institutions } \\
\text { Intensified and sustained collaboration between researchers and } \\
\text { institutions with follow-up projects }\end{array}$ & $\begin{array}{l}\text { Follow-up projects initiated that continue ecosystem degradation } \\
\text { research (NamTip) and wildlife management challenges (ORYCS) } \\
\text { New research questions on wildlife-livestock interactions as well as } \\
\text { bioturbation were developed } \\
\text { Intensified and sustained collaboration between researchers and } \\
\text { institutions }\end{array}$ \\
\hline \multirow{2}{*}{ 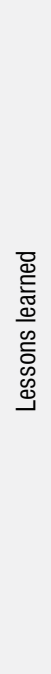 } & Insights & $\begin{array}{l}\text { Long project duration facilitated deep transdisciplinary research } \\
\text { integration as stakeholders could be engaged over a long period } \\
\text { Local institutional stakeholders show more ownership than national } \\
\text { actors } \\
\text { Co-design approach successful as most facilities are operated and } \\
\text { maintained } \\
\text { 'Scientific empathy' more important than knowledge on TDR } \\
\text { methodology }\end{array}$ & $\begin{array}{l}\text { Engagement of local farmers worked via hands-on demonstrations } \\
\text { and field experiments } \\
\text { Farmers' participation required scientists to partly rethink their } \\
\text { initial research focus and approach } \\
\text { Longstanding contacts to target community are valuable catalysts } \\
\text { for trust building in short-term projects }\end{array}$ \\
\hline & Shortcomings & $\begin{array}{l}\text { High turn-over of decision-makers required iterative trust building } \\
\text { Knowledge transfer on national level was bigger challenge than in } \\
\text { the local context } \\
\text { Pre-defined research scope by donor constrained a full bottom-up } \\
\text { process } \\
\text { Unclear responsibilities of institutional stakeholders for continuation } \\
\text { of some activities }\end{array}$ & $\begin{array}{l}\text { Short project duration prevented a deep stakeholder integration } \\
\text { Project output was more scientific (e.g. papers, concepts, models) } \\
\text { and less targeted towards direct practical benefits to farmers } \\
\text { Only the initiated follow-up projects served to create more tangible } \\
\text { practice-oriented output }\end{array}$ \\
\hline \multirow{2}{*}{ 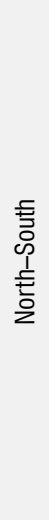 } & Collaboration & $\begin{array}{l}\text { Namibian researchers facilitated the institutional, organisational and } \\
\text { cultural conduction of empirical research } \\
\text { German researchers provided the technical/engineering knowledge } \\
\text { Research team showed mutual respect and acknowledged } \\
\text { individual strengths }\end{array}$ & $\begin{array}{l}\text { Project lead was shared among German and Namibian partners } \\
\text { Namibian researchers engaged in stakeholder consultation, } \\
\text { logistics, student supervision and ecological assessments } \\
\text { German researchers focused primarily on modelling and ecological } \\
\text { assessments }\end{array}$ \\
\hline & Challenges & $\begin{array}{l}\text { Project coordination was assigned to the German partners due } \\
\text { to funding conditions, with challenges for local integration and } \\
\text { communication } \\
\text { Balancing scientific with political interests on national and local } \\
\text { levels regarding project locations and research questions } \\
\text { Adaptation of 'German knowledge system' to carry out empirical } \\
\text { research in Namibia }\end{array}$ & $\begin{array}{l}\text { Project lead was shared but perception of German dominance } \\
\text { persisted } \\
\text { In-kind contributions of the South were not acknowledged } \\
\text { appropriately compared to monetary funds from German donors } \\
\text { Namibian researchers had 'double role' as local (cultural, } \\
\text { organisational) facilitators and researchers, which led to high } \\
\text { workload and potential trade-offs }\end{array}$ \\
\hline
\end{tabular}

Overall, both projects managed to generate impacts on social-ecological structures and processes with different intensities. One major difference between them is the period available and the research focus. While CuveWaters could engage with the local population over a long period and explicitly target technological and institutional interventions, OPTIMASS rather focused on understanding farmer-rangeland interactions. As a result, tangible societal project outcomes are more obvious from the CuveWaters than from the OPTIMASS project.

\section{Lessons learned}

The previous section described the impacts of the projects on multiple societal levels. Now, to critically reflect upon both projects, our expert interviews provide some insights into aspects of TDR that can be considered successful and others that fell short of their expectations.

First, it turns out that project duration is a critical factor to meet TDR requirements. CuveWaters was able to engage with local stakeholders over a period of 10 years while the OPTIMASS project only had 3 years available. In particular, projects that strongly interfere with basic infrastructural settings of a region, such as adjusting the water and food supply systems, require a longer time horizon to embed project activities into local institutional settings as much as possible. Projects with shorter periods do not have the time and monetary means available to do so. For TDR projects with typical periods of about 3 years, the consulted experts identified the need for funding agencies to rethink funding schemes as 
sustainable project impacts are likely to require longer time horizons to evolve. These longer time horizons may be achieved either via longer funding periods or more options for follow-up projects that continue existing collaborations. ${ }^{34}$ However, with longer periods, other challenges appear as, for instance, policy- or decision-makers may change over time, requiring new trust-building incentives from both sides.

Second, following a co-design approach to develop technological and institutional interventions as well as management strategies proved to be successful. CuveWaters developed a 'demand-responsive' approach that serves to design locally adapted institutional set-ups in a mutual learning process between researchers and inhabitants. ${ }^{53}$ In the case of OPTIMASS, the co-design process even required a partial shift of the initial research focus on water management as this was not the main issue to farmers. Their problem perception led to surprises in the research results and at the same time changed the perspective of the analysis. Furthermore, it proved to be beneficial for knowledge transfer to provide hands-on examples and demonstrations of particular solutions on the ground so that inhabitants and farmers could clearly grasp the intended benefits.

Third, the experts interviewed pointed out that openness of involved researchers and stakeholders towards one another are critical success factors for TDR projects. This kind of 'scientific empathy' might even be more important than well-founded knowledge in TDR methods ${ }^{39}$, although certain actors require this set of knowledge to guide the process. Hence, further training in TDR methodology is required, but more emphasis may be given towards the establishment and reproduction of an open-minded atmosphere of mutual respect and acknowledgement. This insight may be of particular importance for the 'undisciplinary journey' of earlycareer researchers who seek to work in a TDR environment with specific challenges, as recently discussed by Haider et al. ${ }^{54}$.

\section{North-South collaboration}

International collaborations between partners from the Global North and Global South in the field of sustainability science have a long and dynamic history ${ }^{55,56}$, with renewed appreciation in the context of the Agenda 2030 process with SDG 17 explicitly targeting strengthened global partnerships ${ }^{5}$. As Saric et al. ${ }^{55}$ conclude from an expert survey, mutual trust, joint decision-making and research agenda setting as well as transparency are considered key features for successful international partnerships. However, in practices, these requirements are often not met for research and development projects..$^{57}$ Here, we intend to provide two insights from our case studies on (1) the 'double-role' of Namibian researchers and (2) equal funding conditions and adequate valuation of in-kind contributions.

First, the consulted experts confirm for both projects that Namibian researchers were confronted with a 'double role'. They were not only required to pursue their specific research questions with associated empirical field work and analytical tasks, but also implicitly required to act as local facilitators for the German researchers by guiding them during the field campaigns as cultural mediators. They strongly engaged with national and local institutional stakeholders, facilitated the cultural and practical set-up of socio-empirical surveys and provided supervision of German and Namibian students, especially during the initial project periods. Although the German researchers also engaged in stakeholder processes and student supervision, they rather took over the scientific part of representing the engineering, social science and ecological disciplines. Overall, this may have led to high workloads for the Namibian researchers in both projects, which could have contributed to a perceived lower recognition and visibility of their scientific contributions.

Second, although both Namibian and German researcher teams shared project responsibilities, monetary funds came from the German ministerial side. This fact contributed to the perception that the German researchers were more dominant in the project team in shaping the overall research agenda than were their Namibian counterparts, as they were considered to be in closer contact to the funding agency. In this context, it was highlighted that in-kind contributions from the Namibian partners were not equally valued as the monetary contributions from
Germany. These in-kind contributions can, however, add up to significant amounts of working hours and infrastructure provision, specifically considering the necessity to act as local facilitators for German partners. Overall, a more transparent and equal funding mechanism for Namibian researchers and students in line with their German counterparts was considered an important component for future collaborations.

Despite these critical perspectives on the North-South collaboration in the case studies, all experts agreed that mutual trust and the acknowledgement of individual strengths was an important cornerstone in both projects. Nevertheless, the issues of high workload for Global South partners and the fair acknowledgement of in-kind contributions to research and development projects are considered relevant points for successful future TDR projects. These findings are in line with current debates on 'helicopter science' and how North-South collaborations could potentially be founded on a more equal basis. ${ }^{35}$

\section{Conclusions}

Current challenges in the Global South can be considered 'wicked' social-ecological problems that require TDR as a mode of science capable of producing 'socially robust' knowledge. Global tools to inform decision-making for sustainable transformations are a good starting point, but local actions are required that take into account relevant particularities. Against this background, we reviewed two TDR projects in Namibia in which challenges in water and food security as well as rangeland sustainability were investigated. Our results provide insights into structural features of TDR projects and their outcomes, lessons learned and challenges in North-South collaborations. With our review as background information, we do not intend to provide new principles or frameworks for TDR implementation. We rather intend to recommend three critical aspects which we think should be considered for successful TDR in the future, for both funders and researchers.

First, we reinforce the recognition that TDR requires revised forms of funding as the mode of research is different from conventional approaches. Achieving positive and long-term project impacts requires more adapted research questions to be formulated that better fit to local real-world problems. In this regard, 'quick initiation funding' or preparatory research phases are promising ways forward. Nevertheless, longer-term funding schemes are required as the initial processes of problem framing and trust building are time-consuming but necessary first steps that provide more benefits the longer collaborations last.

Second, in order to alleviate the power imbalances in terms of monetary funding from the Global North, we recommend acknowledgement of in-kind contributions of Global South partners in a more equitable way and we consider strengthened and independent funding agencies in the Global South as a good way forward (e.g. the Southern African Science Service Centre for Climate Change and Adaptive Land Management). Furthermore, we see the necessity to account for the high workload and double roles of Global South researchers upfront, as this burden is often hidden behind implicit collaboration routines.

Third, while TDR is receiving increased attention, we see the need to make inter- and transdisciplinary activities in a project more explicit to all parties involved. TDR is not just required on paper but needs to be handled explicitly as a critical and continuous activity to which all parties contribute. Hence, we make the case for clear TDR guidance in a project in which responsibilities among project partners are clearly defined and even budgets are allocated to certain activities (e.g. workshops, retreats, co-writing periods). Joint publications with equal contributions from Global North and Global South partners were considered by our interview partners as key elements for interdisciplinary integration that can foster capacity building on both sides. The full potential for knowledge integration and co-production can only be exploited if TDR is considered a 'hard' rather than a 'soft' project component.

\section{Acknowledgements}

This paper builds on research experiences from multiple projects throughout the last years. Special thanks go to our colleagues who were involved in the projects CuveWaters, OPTIMASS, NamTip, ORYCS, 
EPoNA and the Southern African Science Service Centre for Climate Change and Adaptive Land Management. The research was conducted as part of the ORYCS project (01LL1804C) that is funded by the German Federal Ministry of Education and Research (BMBF) in the context of its funding platform 'Research for sustainable development' (FONA).

\section{Competing interests}

We declare that there are no competing interests.

\section{Authors' contributions}

R.L. conceptualised the paper and wrote the initial draft. R.L., S.L. and M.M. reviewed the projects. R.L. and M.M. interviewed the experts and analysed the interview material. R.L., S.L. and M.M. reviewed the draft.

\section{References}

1. UNECA. MDG report: Lessons learned in implementing the MDGs. Addis Ababa: United Nations Economic Commission for Africa; 2015.

2. UN. The Millennium Development Goals report. New York: United Nations; 2015.

3. AUC. Agenda 2063: The Africa we want. Addis Ababa: African Union Commission; 2015

4. Lazarus RJ. Super wicked problems and climate change: Restraining the present to liberate the future. Environ Law Report. 2010;40(8):749-756.

5. UN. The Sustainable Development Goals report. New York: United Nations; 2016

6. Meadows DH, Meadows DL, Randers J, Behrens WW (III). The limits to growth: A report for the Club of Rome's project on the predicament of mankind. New York: Universe Books; 1972.

7. Rockström J, Steffen W, Noone K, Persson A, Chapin FS (III), Lambin EF, et al. A safe operating space for humanity. Nature. 2009;461:472-475. https:// doi.org/10.1038/461472a

8. Raworth K. A doughnut for the Anthropocene: Humanity's compass in the 21st century. Lancet Planet Health. 2017;1(2), e48-e49. https://doi. org/10.1016/S2542-5196(17)30028-1

9. Galaz V, Biermann F, Folke C, Nilsson M, Olsson P. Global environmental governance and planetary boundaries: An introduction. Ecol Econ. 2012;81:1-3. https://doi.org/10.1016/j.ecolecon.2012.02.023

10. Moser SC. Editorial overview: Transformations and co-design: Co-designing research projects on social transformations to sustainability. Curr Opin Environ Sustain. 2016;20:v-viii. https://doi.org/10.1016/j.cosust.2016.10.001

11. Häyhä T, Lucas PL, Van Vuuren DP, Cornell SE, Hoff H. From planetary boundaries to national fair shares of the global safe operating space - How can the scales be bridged? Glob Environ Change. 2016;40:60-72. https://doi. org/10.1016/j.gloenvcha.2016.06.008

12. Balvanera P, Calderón-Contreras R, Castro AJ, Felipe-Lucia MR, Geijzendorffer IR, Jacobs S, et al. Interconnected place-based social-ecological research can inform global sustainability. Curr Opin Environ Sustain. 2017;29:1-7. https://doi.org/10.1016/j.cosust.2017.09.005

13. Mauser W, Klepper G, Rice M, Schmalzbauer BS, Hackmann H, Leemans R, et al. Transdisciplinary global change research: The co-creation of knowledge for sustainability. Curr Opin Environ Sustain. 2013;5:420-431. https://doi. org/10.1016/j.cosust.2013.07.001

14. Mollinga PP. Boundary work and the complexity of natural resources management. Crop Sci. 2010;50:S-1-S-9. https://doi.org/10.2135/ cropsci2009.10.0570

15. Jahn T, Bergmann $M$, Keil F. Transdisciplinarity: Between mainstreaming and marginalization. Ecol Econ. 2012;79:1-10. https://doi.org/10.1016/j. ecolecon.2012.04.017

16. Gall M, Nguyen KH, Cutter SL. Integrated research on disaster risk: Is it really integrated? Int J Disaster Risk Reduct. 2015;12:255-267. https://doi. org/10.1016/j.ijdrr.2015.01.010

17. Pereira L, Frantzeskaki N, Hebinck A, Charli-Joseph L, Drimie S, Dyer M, et al. Transformative spaces in the making: Key lessons from nine cases in the Global South. Sustain Sci. 2020;15:161-178. https://doi.org/10.1007/ s11625-019-00749-x
18. Sitas N, Reyers B, Cundill G, Prozesky HE, Nel JL, Esler KJ. Fostering collaboration for knowledge and action in disaster management in South Africa. Curr Opin Environ Sustain. 2016;19:94-102. https://doi.org/10.1016/j. cosust.2015.12.007

19. Lang DJ, Wiek A, Bergmann M, Stauffacher M, Martens P, Moll P, et al. Transdisciplinary research in sustainability science: Practice, principles, and challenges. Sustain Sci. 2012;7:25-43. https://doi.org/10.1007/s11625011-0149-x

20. Zscheischler J, Rogga S, Lange A. The success of transdisciplinary research for sustainable land use: Individual perceptions and assessments. Sustain Sci. 2018;13:1061-1074. https://doi.org/10.1007/s11625-018-0556-3

21. Liehr S, Kramm J, Jokisch A, Müller K, editors. Integrated water resources management in water-scarce regions: Water harvesting, groundwate desalination and water reuse in Namibia. London: IWA Publishing; 2018

22. Blaum N, Lohmann D, Geißler K. A joint Namibian-German research project. University of Potsdam. Potsdam: Plant Ecology \& Nature Conservation; 2018.

23. Roux DJ, Stirzaker RJ, Breen CM, Lefroy EC, Cresswell HP. Framework for participative reflection on the accomplishment of transdisciplinary research programs. Environ Sci Policy. 2010;13:733-741. https://doi.org/10.1016/j. envsci.2010.08.002

24. Freeth $\mathrm{R}$, Caniglia G. Learning to collaborate while collaborating: Advancing interdisciplinary sustainability research. Sustain Sci. 2020;15:247-261. https://doi.org/10.1007/s11625-019-00701-z

25. Cundill G, Roux DJ, Parker JN. Nurturing communities of practice for transdisciplinary research. Ecol Soc. 2015;20(2), Art. \#22. https://doi. org/10.5751/ES-07580-200222

26. Margoluis R, Stem C, Swaminathan V, Brown M, Johnson A, Placci G, et al. Results chains: $A$ tool for conservation action design, management, and evaluation. Ecol Soc. 2013;18(3), Art. \#22. https://doi.org/10.5751/ES05610-180322

27. Bogner A, Menz W. Das theoriegenerierende Experteninterview: Erkenntnisse Wissensformen, Interaktion [The theory-generating expert interview: Findings, forms of knowledge, interaction]. In: Bogner A, editor. Das Experteninterview: Theorie, Methode, Anwendung. 2. Aufl. Opladen: Leske + Budrich; 2005. p. 33-70. German

28. Defila $\mathrm{R}$, Di Giulio A. Integrating knowledge: Challenges raised by the "Inventory of Synthesis". Futures. 2015;65:123-135. https://doi. org/10.1016/j.futures.2014.10.013

29. Stock P, Burton RJF. Defining terms for integrated (multi-inter-transdisciplinary) sustainability research. Sustainability. 2011;3:1090-1113. https://doi.org/10.3390/su3081090

30. Roux DJ, Nel JL, Cundill G, O'Farrell, P, Fabricius C. Transdisciplinary research for systemic change: Who to learn with, what to learn about and how to learn. Sustain Sci. 2017;12:711-726. https://doi.org/10.1007/s11625-0170446-0

31. Reyers B, Roux DJ, Cowling RM, Ginsburg AE, Nel JL, O'Farrell, P. Conservation planning as a transdisciplinary process. Conserv Biol. 2010;24:957-965. https://doi.org/10.1111/j.1523-1739.2010.01497.x

32. Nel JL, Roux DJ, Driver A, Hill L, Maherry AC, Snaddon K, et al. Knowledge co-production and boundary work to promote implementation of conservation plans. Conserv Biol. 2016;30:176-188. https://doi.org/10.1111/cobi.12560

33. Liehr S, Röhrig J, Mehring M, Kluge T. How the social-ecological systems concept can guide transdisciplinary research and implementation: Addressing water challenges in central northern Namibia. Sustainability. 2017:9:1109. https://doi.org/10.3390/su9071109

34. Luthe T. Success in transdisciplinary sustainability research. Sustainability 2017;9:71. https://doi.org/10.3390/su9010071

35. Giller KE. Grounding the helicopters. Geoderma. 2020;373:114302. https:// doi.org/10.1016/j.geoderma.2020.114302

36. Woodhouse P, Muller M. Water governance - An historical perspective on current debates. World Dev. 2017;92:225-241. https://doi.org/10.1016/j. worlddev.2016.11.014 
37. Kluge T. Integrated water resources management (IWRM) in water-scarce regions - from theory to implementation. In: Liehr S, Kramm J, Jokisch A, et al., editors. Integrated water resources management in water-scarce regions: Water harvesting, groundwater desalination and water reuse in Namibia. London: IWA Publishing; 2018. p. 1-7.

38. Sala OE, Yahdjian L, Havstad K, Aguiar MR. Rangeland ecosystem services: Nature's supply and humans' demand. In: Briske DD, editor. Rangeland systems. Cham: Springer International Publishing; 2017. p. 467-489.

39. Bergmann M, Jahn T, Knobloch T, Krohn W, Pohl C, Schramm E, et al. Methods for transdisciplinary research. Frankfurt: Campus Verlag; 2012.

40. Mehring M, Bernard B, Hummel D, Liehr S, Lux A. Halting biodiversity loss: How social-ecological biodiversity research makes a difference. Int $J$ Biodivers Sci Ecosyst Serv Manag. 2017;13:172-180. https://doi.org/10.10 80/21513732.2017.1289246

41. Tietjen B. Same rainfall amount different vegetation - How environmental conditions and their interactions influence savanna dynamics. Ecol Modell. 2016;326:13-22. https://doi.org/10.1016/j.ecolmodel.2015.06.013

42. Polak M, Kluge T. Water governance in Namibia: Progress in and challenges of putting IWRM into practice. In: Liehr S, Kramm J, Jokisch A, et al., editors. Integrated water resources management in water-scarce regions: Water harvesting, groundwater desalination and water reuse in Namibia. London: IWA Publishing; 2018. p. 23-26.

43. Deffner J, Birzle-Harder B. Social adoption, experiences and constraints of small-scale horticulture with harvested rain- and floodwater. In: Liehr S, Kramm J, Jokisch A, et al., editors. Integrated water resources management in water-scarce regions: Water harvesting, groundwater desalination and water reuse in Namibia. London: IWA Publishing; 2018. p. 111-117.

44. Bischofberger J, Schuldt-Baumgart N, Röhrig J, Schulz 0, Neugart M. Knowledge exchange between research and practice. In: Liehr S, Kramm J, Jokisch A, et al., editors. Integrated water resources management in waterscarce regions: Water harvesting, groundwater desalination and water reuse in Namibia. London: IWA Publishing; 2018. p. 225-234.

45. Berkes F. Sacred ecology. 4th ed. London: Routledge; 2018.

46. Fleischman F, Briske DD. Professional ecological knowledge: An unrecognized knowledge domain within natural resource management. Ecol Soc. 2016;21(1), Art. \#32. https://doi.org/10.5751/ES-08274-210132
47. Mobjörk M. Consulting versus participatory transdisciplinarity: A refined classification of transdisciplinary research. Futures. 2010;42:866-873. https://doi.org/10.1016/j.futures.2010.03.003

48. Bischofberger J, Reutter C, Liehr S, Schulz O. The integration of stakeholder knowledge - How do Namibian farmers perceive natural resources and their benefits? Paper presented at: Conference on International Research and Food Security; 2016 September 18-21; Vienna, Austria.

49. OPTIMASS. Rangeland in a changing world: The management and understanding of Namibian savanna rangelands. Paper presented at: 21st Namibian National Rangeland Forum; 2017 July 17-19; Otjiwarongo, Namibia.

50. Technical University of Darmstadt. EPoNa Project [webpage on the Internet]. No date [cited 2020 Apr 28]. Available from: http://epona-africa.com/index. php/en/

51. University of Bonn. NamTip Project [webpage on the Internet]. No date [cited 2020 Apr 28]. Available from: https://www.namtip.uni-bonn.de/?set language $=$ en

52. University of Potsdam. OPTIMASS Project [webpage on the Internet]. No date [cited 2019 Jun 12]. Available from: https://www.optimass.org/index.html

53. Zimmermann M, Jokisch A, Deffner J, Brenda M, Urban W. Stakeholde participation and capacity development during the implementation of rainwater harvesting pilot plants in central northern Namibia. Water Supply. 2012;12:540-548. https://doi.org/10.2166/ws.2012.024

54. Haider LJ, Hentati-Sundberg J, Giusti M, Goodness J, Hamann M, Masterson $V A$, et al. The undisciplinary journey: Early-career perspectives in sustainability science. Sustain Sci. 2018:13:191-204. https://doi.org/10.1007/s11625017-0445-1

55. Saric J, Blaettler D, Bonfoh B, Hostettler S, Jimenez E, Kiteme B, et al. Leveraging research partnerships to achieve the 2030 Agenda Experiences from North-South cooperation. Gaia. 2019;28:143-150. https://doi. org/10.14512/gaia.28.2.13

56. Gaillard JF. North-South research partnership: Is collaboration possible between unequal partners? Knowledge Policy. 1994;7:31-63. https://doi. org/10.1007/BF02692761

57. Bradley M. North-South research partnerships: Challenges, responses and trends: A literature review and annotated bibliography. Ottawa: Spatial Initiatives Division (IDRC); 2007 